\title{
Program Pengurangan Sampah Plastik Melalui Kebijakan Kantong Plastik Berbayar di Ritel Modern
}

\author{
Natalia Lusnita \\ Sekolah Tinggi IImu Komunikasi LSPR, Jakarta, Indonesia
}

\begin{abstract}
ABSTRAK
Sampah plastik telah menjadi permasalahan yang rumit dari tahun ke tahun dan menjadi perhatian dari Pemerintah. Berbagai usaha dilakukan untuk mengurangi timbunan sampah plastik hingga akhirnya Pemerintah mengeluarkan Kebijakan kantong plastik berbayar dengan dikeluarkannya Surat Edaran Kementerian Lingkungan Hidup dan Kehutanan Direktorat Jenderal Pengelolaan Sampah, Limbah dan Bahan Berbahaya dan Beracun Nomor: S.1230/PSLB3-PS/2016 tentang Harga dan Mekanisme Penerapan Kantong Plastik Berbayar. Tujuan program ini adalah untuk mensosialisasikan kantong plastik berbayar di ritel modern sebagai salah satu upaya mengurangi sampah di Indonesia. Hasil evaluasi menunjukkan selama 4 bulan dilakukan uji coba, telah mengurangi penggunaan kantong plastik sebesar $55 \%$.
\end{abstract}

Kata kunci: Strategi Komunikasi, Kebijakan, Sampah Plastik

\begin{abstract}
Plastic waste has become a complicated problem from year to year and is a concern of the Government. Various attempts were made to reduce the accumulation of plastic waste until finally the Government issued a paid plastic bag policy with the issuance of a Circular Letter of the Ministry of Environment and Forestry Directorate General of Waste, Hazardous and Toxic and Waste Management Number: S.1230 / PSLB3-PS / 2016 concerning Prices and Mechanisms for the Application of Paid Plastic Bags. The aim of this program is to socialize paid plastic bags in modern retail as an effort to reduce waste in Indonesia. The evaluation results show that for 4 months of testing, it has reduced the use of plastic bags by $55 \%$.
\end{abstract}

Keywords: Communication Strategy, Policy, Plastic Waste

CONTACT Natalia Lusnita. Sekolah Tinggi Ilmu Komunikasi LSPR, Jakarta, Indonesia. Sudirman Park Campus, Jl. Jend. Sudirman No.Kav. 32, RT.12/RW.11, Karet Tengsin, Kota Jakarta Pusat, Daerah Khusus Ibukota Jakarta 10250. Email: lianat80@gmail.com 


\section{PENDAHULUAN}

Berbagai macam barang atau produk berbahan plastik digunakan dalam keseharian manusia. Bahan plastik sangat disukai karena memiliki sifat yang praktis, ringan dan kedap air, hal ini sesuai dengan kehidupan manusia yang memiliki mobilitas tinggi. Salah satu produk berbahan plastik yang kerap digunakan masyarakat dalam kehidupan sehari-hari adalah kantong plastik belanjaan sekali pakai. Masyarakat kerap menggunakan kantong plastik sekali pakai dengan tidak bijak. Contohnya, ketika konsumen membeli pisang, minuman soda dan sabun cuci piring maka petugas kasir toko akan menggunakan minimal 3 kantong plastik yaitu 1 kantong plastik untuk pisang, 1 kantong plastik untuk minuman soda dan 1 kantong plastik untuk sabun cuci piring. Selanjutnya, kantong plastik sekali pakai ini akan menjadi sampah yang membutuhkan waktu 20 sampai 1000 tahun untuk akhirnya dapat diurai.

Seriusnya permasalahan sampah plastik inilah yang melatarbelakangi Kementerian Lingkungan Hidup dan Kehutanan (KLHK) melakukan uji coba penerapan kantong plastik berbayar terhitung sejak 21 Februari 2016. Berdasarkan hasil pertemuan Kementerian Lingkungan Hidup dan Kehutanan (KLHK) dengan Badan Perlindungan Konsumen Nasional (BPKN), Yayasan Lembaga Konsumen Indonesia (YLKI), dan Asosiasi Pengusaha Ritel Seluruh Indonesia (APRINDO); Dirjen Pengelolaan Sampah, Limbah dan Bahan Berbahaya dan Beracun KLHK mengeluarkan kebijakan berupa Surat Edaran Nomor: S.1230/PSLB3-PS/2016 tentang Harga dan Mekanisme Penerapan Kantong Plastik Berbayar di seluruh gerai pasar ritel modern di Indonesia. Surat edaran ini ditujukan kepada kepala daerah dan pelaku usaha, mengenai penerapan plastik berbayar di seluruh gerai pasar modern di Indonesia. Dalam surat edaran tersebut disepakati harga jual kantong plastik selama uji coba penerapan kantong plastik berbayar adalah sebesar minimal Rp 200 sudah termasuk Pajak Pertambahan Nilai (PPN).

Di berbagai negara lain kebijakan kantong plastik bukanlah hal yang baru. Di Inggris dan Irlandia, kantong plastik berbayar telah berhasil mengurangi $90 \%$ penggunaan kantong plastik. Di China kantong plastik telah dilarang. Terdapat 31 negara di Eropa, 18 di Afrika, 7 di Amerika dengan 132 kota, 12 kota di Australia dan 14 negara Asia termasuk Malaysia yang telah menerapkan kantong plastik berbayar (data KLHK).

Surat Edaran pertama yang dikeluarkan terkait pengurangan kantong plastik adalah Surat Edaran Direktorat Jenderal Pengelolaan Sampah, Limbah dan Bahan Berbahaya dan Beracun Nomor SE-06/PSLB3-PS/2015 tentang Langkah Antisipasi Penerapan Kebijakan Kantong Plastik Berbayar Pada Usaha Ritel Modern (SE 6/2015). Dalam SE ini pemerintah menganggap bahwa kebijakan kantong plastik berbayar merupakan salah satu strategi guna menekan laju timbulan sampah plastik. 
Ketentuan mengenai kantong plastik berbayar diatur dalam Surat Edaran Kementerian Lingkungan Hidup dan Kehutanan Direktorat Jenderal Pengelolaan Sampah, Limbah dan Bahan Berbahaya dan Beracun Nomor: S.1230/PSLB3-PS/2016 tentang Harga dan Mekanisme Penerapan Kantong Plastik Berbayar.

Beberapa ketentuan dalam SE 1230/2016 ini antara lain: (1) Pengusaha ritel tidak lagi menyediakan kantong plastik secara cuma-cuma kepada konsumen. Apabila konsumen masih membutuhkan kantong plastik maka konsumen diwajibkan membeli kantong plastik dari gerai ritel; (2) Terkait harga kantong plastik, Pemerintah, BPKN, YLKI, dan APRINDO menyepakati harga jual kantong plastik selama uji coba penerapan kantong plastik berbayar sebesar minimal Rp 200 per kantong sudah termasuk Pajak Pertambahan Nilai (PPN); (3) Harga kantong plastik akan dievaluasi oleh Pemerintah dan Pemerintah Daerah bersama APRINDO setelah uji coba berjalan sekurang-kurangnya 3 (tiga) bulan; (4) Terkait jenis kantong plastik yang disediakan oleh pengusaha ritel, Pemerintah, BPKN, YLKI, dan APRINDO menyepakati agar spesifikasi kantong plastik tersebut dipilih yang menimbulkan dampak lingkungan paling minimal dan harus memenuhi standar nasional yang dikeluarkan oleh Pemerintah atau lembaga independen yang ditugaskan untuk itu; (5) APRINDO menyepakati bahwa mereka berkomitmen mendukung kegiatan pemberian insentif kepada konsumen, pengelolaan sampah, dan pengelolaan lingkungan hidup melalui program tanggung jawab sosial perusahaan (Corporate Sosial Responsibility, CSR) dengan mekanisme yang akan diatur oleh masing-masing pengusaha ritel. (6) Ketentuan ini juga berlaku untuk usaha ritel modern yang bukan anggota APRINDO.

Kebijakan kantong plastik berbayar diyakini sebagai salah satu strategi yang dapat menekan laju timbunan sampah kantong plastik yang selama ini menjadi bahan pencemar bagi lingkungan hidup. Sejak diberlakukannya Surat Edaran tersebut, maka pengusaha ritel modern tidak lagi menyediakan kantong plastik secara gratis kepada konsumen. Apabila konsumen membutuhkan kantong plastik maka diwajibkan membeli kantong plastik sesuai harga yang telah ditentukan. Melalui kebijakan kantong plastik berbayar ini konsumen diharapkan dapat mengurangi penggunaan kantong plastik dan peritel yang selama ini sebagai salah satu pengguna kantong plastik sekali pakai dapat membantu mengedukasi konsumen agar mengurangi penggunaan kantong plastik.

Guna menyukseskan kebijakan kantong plastik berbayar maka Kementerian Lingkungan Hidup dan Kehutanan (KLHK) bekerjasama dengan pengusaha ritel modern melakukan program komunikasi untuk mengedukasi dan membujuk konsumen agar mengurangi atau berhenti menggunakan kantong plastik sekali pakai.

Komunikasi bukan lagi sekedar upaya memberikan informasi kepada seseorang agar menjadi tahu, melainkan melalui komunikasi seseorang diharapkan dapat melakukan atau melaksanakan suatu kegiatan atau aktivitas tertentu sesuai dengan pesan yang disampaikan 
melalui komunikasi tersebut. Oleh sebab itu, kegiatan komunikasi memerlukan strategi, karena dengan strategi pesan yang disampaikan harus dapat diterima sehingga respon yang didapat juga sesuai dengan harapan komunikator.

Strategi komunikasi digunakan untuk mencapai suatu tujuan, sehingga dalam strategi komunikasi pada hakikatnya harus ada perencanaan (planning) dan manajemen (management) untuk dapat menunjukkan taktik operasional dalam mencapai tujuan tersebut (Effendi, 2009:32). Dengan demikian, pendekatan yang dilakukan dapat berbeda-beda mengikuti pada situasi dan kondisi yang dihadapi.

Pakar lain mendefenisikan strategi komunikasi adalah keseluruhan keputusan kondisional tentang tindakan yang akan dijalankan guna mencapai tujuan, jadi merumuskan suatu strategi komunikasi berarti memperhitungkan kondisi dan situasi (ruang dan waktu) yang dihadapi dan yang akan dihadapi di masa depan, guna mencapai efektivitas. Dengan strategi komunikasi ini berarti dapat ditempuh dengan beberapa cara dengan menggunakan komunikasi secara sadar untuk menciptakan perubahan diri khalayak dengan mudah dan cepat (Arifin, 2004:10).

Strategi komunikasi menentukan berhasil tidaknya sebuah kegiatan komunikasi secara efektif. Strategi komunikasi, baik secara makro (planned multimedia strategy) maupun mikro (single communication medium strategy) mempunyai fungsi ganda (Effendy, 2009:28), yaitu: (1) Menyebarluaskan pesan komunikasi yang bersifat informatif, persuasif, dan instruktif secara sistematis kepada sasaran untuk memperoleh hasil yang optimal; (2) Menjembatani "kesenjangan budaya" (cultural gap) akibat kemudahan diperolehnya dan kemudahan dioperasionalkannya media massa yang begitu ampuh, yang jika dibiarkan akan merusak nilainilai budaya

Tujuan penerapan strategi komunikasi yang dikemukakan oleh R. Wayne Pace, Brent D. Petersondan M Dallas Burnet dalam Effendy (2009:32) terdiri atas tiga tujuan utama yaitu: (1) To Secure Understanding yaitu memastikan bahwa terjadi suatu pengertian dalam berkomunikasi, memberikan pengaruh kepada komunikan melalui pesan-pesan yang disampaikan untuk mencapai tujuan tertentu dari organisasi.; (2) To Establish Acceptance yaitu bagaimana cara penerimaan itu terus dibina dengan baik, setelah komunikan menerima dan mengerti pesan yang disapaikan; (3) To Motivate Action yaitu penggiat untuk memotivasinya. Komunikasi selalu memberi pengertian yang diharapkan dapat mempengaruhi atau mengubah perilaku komunikan sesuai dengan keinginan komunikator. Jadi strategi komunikasi ditujukan untuk mengubah perilaku komunikan.

Dari beberapa pengertian di atas, maka strategi komunikasi erat hubungan dan kaitannya dengan tujuan yang hendak dicapai dengan konsekuensi-konsekuensi (masalah) yang harus diperhitungkan, kemudian merencanakan bagaimana mencapai konsekuensi-konsekuensi 
sesuai dengan hasil yang diharapkan atau dengan kata lain tujuan yang hendak dicapai. Arifin (2004:58) menyebutkan terdapat empat langkah dalam merumuskan strategi komunikasi yaitu: (1) Mengenal khalayak (2)Menyusun pesan (3) Menetapkan metode (4) Seleksi dan penggunaan media.

Setelah mengenal khalayak, tahapan selanjutnya adalah bagaimana menyusun pesan sesuai dengan tema dan materi. Karena komunikasi diharapkan dapat mempengaruhi khalayak, maka pesan harus dirancang sedemikian rupa untuk mampu membangkitkan perhatian dari khalayak yang dituju. Untuk melakukan ini, maka komunikator dapat menggunakan pendekatan yang disebut $A-A$ Procedure atau from Attention to Action Procedure yaitu bagaimana membangkitkan perhatian untuk selanjutnya menggerakkan seseorang atau orang banyak untuk melakukan suatu keaiatan sesuai tujuan yang telah dirumuskan oleh komunikator.

AA Procedure sendiri merupakan penyederhanaan dari proses komunikasi yang disingkat AIDDA (Attention, Interest, Desire, Decision, Action). Artinya proses dimulai dengan bagaimana mendapatkan perhatian (attention) yang dapat menumbuhkan minat dan kepentingan yang sama (interest) sehingga komunikasn memiliki hasrat (desire) untuk menerima pesan tersebut dan pada akhirnya mengambil keputusan (decision) untuk melanjutkannya dalam tindakan nyata (Arifin 2004:44).

Pada akhirnya, tujuan dilakukannya strategi komunikasi adalah bagaimana dapat menciptakan perubahan pada khalayak karena itu merupakan hasil dari proses komunikasi yang tidak dapat dielakkan. Beberapa syarat yang harus dipertimbangkan dalam mendukung suksesnya suatu pesan adalah (Arifin, 2004:46), (1) Direncanakan dan disampaikan sedemikian rupa sehingga menarik perhatian dari sasaran yang dituju; (2) Menggunakan tanda-tanda yang dirasakan pada pengalaman yang sama antara sumber dan sasaran sehingga kedua pengertian itu bertemu; (3) Membangkitkan kebutuhan pribadi daripada sasaran dan menyarankan cara-cara mencapai kebutuhan itu; (4) Menyarankan sesuatu jalan untuk memperoleh kebutuhan yang layak bagi situasi kelompok dimana kesadaran pada saat digerakkan untuk memberikan jawaban yang dikehendaki.

Tahapan berikutnya setelah mengidentifikasi khalayak dan menyusun pesan adalah menentukan metode penyampaian yang akan digunakan. Beberapa metode komunikasi yang efektif ditawarkan oleh Arifin (2004:73) yaitu: (1) Redundancy (repetition). Metode ini adalah mengulang-ulang pesan agar mendapatkan perhatian dari khalayak sehingga lebih mudah untuk diingat dan menempel dalam ingatan khalayak. Dengan metode ini juga komunikator mendapat kesempatan untuk memperbaiki kekurangan yang terjadi dari penyampaian sebelumnya; (2) Canalizing. Pesan disesuaikan dengan kerangka referensi dan pengalaman lapangan dari khalayak. Komunikator menyediakan saluran-saluran tertentu untuk menguasai motif-motif yang ada pada khalayak; (3) Informative. Pesan dibentuk bersifat 
informatif dengan tujuan untuk mempengaruhi khalayak dengan cara memberikan penerangan yaitu penyampaian pesan apa adanya atau sesungguhnya. Dengan kata lain penyampaian informasi sesuai data, pendapat dan fakta yang benar dan dapat dipertanggungjawabkan kebenarannya. Dengan demikian komunikan diberi kesempatan untuk menilai, dan mengambil keputusan secara sehat; (4) Persuasive. Artinya membujuk. Khalayak tidak diberikan kesempatan untuk banyak berfikir karena pesan dikemas untuk menggugah pikiran dan perasaannya; (5) Educative. Merupakan metode dengan cara mendidik dimana pesan berisi pendapat, fakta dan pengalaman-pengalaman serta ide kepada khalayak, apa adanya dari segi kebenarannya, dengan sengaja, teratur dan berencana, dengan tujuan mengubah tingkah laku manusia ke arah yang diinginkan; (6) Cursive. Mempengaruhi khalayak dengan cara memaksa, sehingga pesan selain berisi pendapat juga berisi ancaman-ancaman. Biasanya metode ini dimanifestasikan dalam bentuk peraturan, perintah, intimidasi agar pelaksanaannya lebih lancar.

Langkah terakhir adalah seleksi dan penggunaan media. Penggunaan media dapat dilakukan dengan cara tatap muka (face to face) ataupun media massa tergantung dari besaran audience yang dituju. Sasaran yang terdiri dari beberapa orang saja dan lokasi terjangkau maka dapat dilakukan secara tatap muka, jika sasaran adalah internal publik maka dilakukan pertemuan-pertemuan, dan jika sasaran adalah masyarakat luas maka dapat menggunakan saluran komunikasi media massa.

Dengan keempat langkah tersebut maka kita dapat mengetahui strategi komunikasi yang digunakan oleh Kementerian Lingkungan Hidup dan Kehutanan dalam mensosialisasikan program kantong plastik berbayar.

Istilah "plastik" mencakup bahan organik, seperti unsur karbon (C), hidrogen $(H)$, nitrogen $(N)$, klorin $(\mathrm{Cl})$ dan belerang $(\mathrm{S})$, yang memiliki sifat yang serupa dengan yang tumbuh secara alami dalam bahan organik seperti kayu, tanduk dan rosin. Plastik adalah polimer. Definisi paling sederhana dari polimer adalah sesuatu yang terbuat dari banyak unit. Pikirkan sebuah polimer sebagai rantai. Setiap link rantai adalah "-mer" atau unit dasar yang biasanya terbuat dari karbon, hidrogen, oksigen dan / atau silicon. Kantong plastik terbuat dari etilen, gas yang diproduksi sebagai produk sampingan dari produksi minyak, gas dan batu bara. Etilen dibuat menjadi polimer (rantai molekul etilena) yang disebut polietilen. Zat ini, yang juga dikenal sebagai polyethylene atau polythene, dibuat menjadi pelet, yang digunakan oleh pabrikan plastik untuk menghasilkan berbagai barang, termasuk kantong plastik (Gogte, M. 2009).

Ada dua jenis tas belanja plastik - tas ringan yang biasa kita dapatkan dari supermarket dan gerai makanan lainnya, dan jenis tas belanja berat yang kita dapatkan dari gerai ritel lainnya, seperti toko pakaian. HDPE (High Density Polyethylene) bersifat kaku, tipis dan tidak transparan atau buram. HDPE (polimer etilena dengan kerapatan berkisar antara 0,941 sampai 0,965 gram per sentimeter kubik) biasanya digunakan dalam tas kelontong. HDPE 
aman untuk digunakan karena kemampuan untuk mencegah reaksi kimia antara kemasan plastik dengan makanan/minuman yang dikemasnya. LDPE $(0,916$ sampai 0,925 gram per sentimeter kubik) atau tas polietilen dengan kepadatan rendah yang tebal dan lembut dan dapat terlihat transparan dan glossy. LDPE digunakan dalam tas belanja biasanya dengan gagang yang terpasang. Tidak seperti HDPE, bahan LDPE ini lebih sulit untuk dihancurkan (Gogte, M.2009).

\section{Gambar 1. Kantong Plastik HDPE \& LDPE}

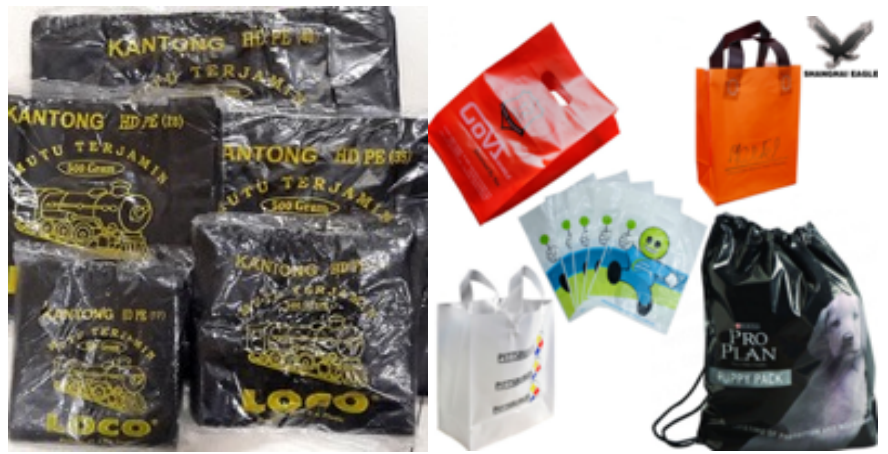

Sumber: google.co.id/image/indonetwork.co.id

Dibalik kemudahan, kepraktisan dan harga yang murah yang membuat manusia sangat tergantung dengan plastik, banyak masyarakat yang tidak mengetahui bahaya dari plastik dan yang dapat disebabkan oleh plastik. Plastik memiliki tekstur yang kuat dan tidak mudah terdegradasi oleh mikroorganisme tanah. Sering kali untuk menghindari pencemaran terhadap tanah maka ada yang membakar sampah plastik, padahal asap yang dihasilkan dari pembakaran tersebut juga berbahaya karena mengeluarkan asap toksik yang dapat menyebabkan gangguan kesuburan. Penggunaan plastik sebagai wadah dalam industri makanan juga berisiko saat zat warna dalam plastik terkena panas dan terurai menjadi bentuk radikal menyebabkan penyakit. Selain faktor kesehatan, plastik juga menyebabkan rusaknya lingkungan hidup yaitu pembuangan limbah sampah plastik. Diperlukan waktu puluhan bahkan ratusan tahun untuk membuat sampah kantong plastik benar-benar terurai. Dibutuhkan waktu 1000 tahun agar plastik dapat terurai oleh tanah secara terdekomposisi atau terurai laut dapat mencemari biota laut. dengan sempurna. Saat terurai, partikel-partikel plastik akan mencemari tanah dan air tanah.

Kantong plastik ini juga membawa dampak pada kehidupan laut. Sampah plastik yang terbawa arus Kantong plastik telah membunuh sekitar 100.000 paus, anjing laut, kura-kura dan hewan laut lainnya setiap tahun di seluruh dunia. Di dalam air, kantong plastik bisa terlihat salah bagi hewan laut seperti burung, paus, anjing laut dan kura-kura yang menelan kantong tersebut dan kemudian mati karena penyumbatan pada usus. Kantong plastik adalah sampah kelima paling umum yang ditemukan di pantai (Gogte, M.2009). 
Ritel merupakan mata rantai yang penting dan terakhir dalam suatu proses distribusi. Ritel adalah serangkaian kegiatan yang memasarkan produk atau layanan kepada konsumen akhir untuk keperluan pribadi atau rumah tangga mereka. Bisnis ritel adalah penjualan barang secara eceran pada berbagai tipe gerai seperti kios, pasar, department store, butik dan lainlain (termasuk juga penjualan dengan sistem delivery service). Melalui ritel, suatu produk dapat bertemu langsung dengan penggunanya. Bisnis ritel di Indonesia dapat dibedakan menjadi 2 kelompok besar, yakni Ritel Tradisional dan Ritel Modern. Ritel modern pada dasarnya merupakan pengembangan dari ritel tradisional. Kemajuan perekonomian, teknologi dan perubahan gaya hidup menuntut kenyamanan lebih dalam berbelanja yang tidak mau berdesak-desakan di pasar tradisional yang biasanya kotor dan tidak tertata rapi sehingga memunculkan berbagai format ritel.

Ritel modern pertama kali hadir di Indonesia saat Toserba Sarinah didirikan pada tahun 1962. Menurut Asosias Pengusaha Ritel Indonesia (APRINDO), bisnis ritel mulai berkembang pada kisaran tahun 1980-an seiring dengan berkembangnya perekonomian Indonesia (Soliha, E.2008). Hingga pada awal dekade 1990-an merupakan tonggak sejarah masuknya ritel asing di Indonesia ditandai dengan beroperasinya ritel terbesar Jepang yaitu 'Sogo'. Ritel modern kemudian berkembang begitu pesat saat pemerintah berdasarkan Kepres no. 99 th 1998, mengeluarkan bisnis ritel dari negative list bagi Penanaman Modal Asing dimana sebelum adanya Kepres ini, jumlah peritel asing sangat terbatas (Pandin, 2009).

Pengecer asing seperti Makro (Belanda), Carrefour (Perancis), dan Giant (Malaysia, yang kemudian digandeng oleh PT Hero Supermarket TBk) meramaikan industri ritel dengan dibuka dan tersebarnya gerai-gerai mereka di kota-kota besar seperti Jakarta, Semarang, Bandung, dll. Saat ini jenis-jenis ritel modern di Indonesia sangat banyak meliputi Pasar Modern, Pasar swalayan, Department store, Boutique, Factory Outlet, Specialty Store, Trade Centre, dan Mall/Supermall/Plaza. Pasar modern disebut-sebut sebagai format ritel yang mengalami perkembangan sangat baik karena merupakan tempat penjualan barang-barang kebutuhan rumah tangga dengan cara swalayan atau mengambil sendiri barang dari rak dagangan dan membayar ke kasir. Karena itu pasar dengan format ini disebut juga Pasar Swalayan.

Perusahaan ritel dapat dikategorikan berdasarkan ciri - ciri tertentu, antara lain: (1) Discount stores, adalah toko pengecer yang menjual berbagai macam barang dengan harga yang murah dan memberikan pelayanan yang minimum; (2) Speciality stores, merupakan toko eceran yang menjual barang - barang jenis lini produk tertentu saja yang bersifat spesifik; (3) Departemen stores, adalah suatu toko eceran berskala besar yang pengelolaannya dipisah dan dibagi menjadi bagian departemen - departemen yang menjual macam barang yang berbeda - beda; (4) Convenience stores, adalah toko pengecer yang menjual jenis item produk yang terbatas, bertempat ditempat yang nyaman dan jam buka yang panjang; (5) Catalog stores, merupakan suatu jenis toko yang banyak memberikan informasi produk melalui media katalog yang dibagikan kepada para konsumen potensial; (6) Chain stores, adalah toko 
pengecer yang memiliki lebih dari satu gerai dan dimiliki oleh perusahaan yang sama; (7) Supermarket, adalah toko eceran yang menjual berbagai macam produk makanan dan juga sejumlah kecil produk non-makanan dengan sistem konsumen melayani dirinya sendiri (swalayan); (8) Hypermarkets, adalah toko eceran yang menjual jenis barang dalam jumlah yang sangat besar atau lebih dari 50.000 item dan mencakup banyak jenis produk. Hypermarket merupakan gabungan antara retailer toko diskon dengan hypermarket; (9) Minimarket, merupakan adalah semacam toko kelontong yang menjual segala macam barang dan makanan, namun tidak sebesar dan selengkap supermarket.

\section{METODE PELAKSANAAN}

Untuk mendapatkan gambaran yang lengkap mengenai strategi komunikasi yang dilakukan oleh Kementerian Lingkungan Hidup dan Kehutanan (KLHK) dalam mensosialisasikan uji coba kebijakan kantong plastik berbayar yang diterapkan di ritel modern, maka dilakukan wawancara mendalam dengan menggunakan pedoman wawancara kepada berbagai pihak yang terlibat dalam pengambilan keputusan dan pelaksanaan kebijakan kantong plastik berbayar, yaitu Kementerian Lingkungan Hidup dan Kehutanan sebagai komunikator, Asosiasi Pengusaha Ritel Indonesia (APRINDO) dan Yayasan Lembaga Konsumen Indonesia (YLKI).

\section{HASIL DAN PEMBAHASAN}

Dua konteks besar dalam pengelolaan sampah adalah pengurangan sampah dan penanganan sampah. Berbicara mengenai pengurangan sampah berarti berbicara bagaimana mengurangi sampah sejak dari sumber (hulu), jadi jelas berbeda dengan penanganan yang artinya dimana ada sampah lalu bagaimana cara menanganinya. Dan karena hal ini adalah sesuatu yang baru di Indonesia, maka KLHK mengambil strategi dengan cara mengkomunikasikan terlebih dahulu mengenai ide ini kepada beberapa stakeholder terkait yaitu Kementerian Perdagangan, Kementerian Perindustrian, Ritel, dan karena nantinya ide ini akan memiliki dampak kepada masyarakat sebagai konsumen sehingga YLKI dan BPKN (Badan Perlindungan Konsumen Nasional) turut dilibatkan. Tahapan ini dapat dikatakan adalah strategi KLHK dalam mengenal khalayaknya. Menurut Bapak Ujang Solihin Sidik selaku Deputy Director Produk dan Kemasan di Direktorat Pengelolaan Sampah, Limbah dan Bahan Beracun Berbahaya (PSLB3) KLHK, yang juga merupakan anggota tim formulasi peraturan mengenai Kantong Plastik Berbayar pada usaha ritel modern, pelaksanaan komunikasi mengenai ide ini telah dimulai sejak tahun 2015 melalui banyak pertemuan dan diskusi karena KLHK menyadari bahwa diperlukan jangka waktu bagi seseorang dari mulai mengetahui hingga memutuskan untuk menerima atau menolak suatu hal baru. Pemilihan pasar ritel modern dan bukan pasar rakyat yang disasar terlebih dahulu karena penerimaan akan ide baru lebih mudah didapat dari pihak dengan sistem sosial yang lebih tinggi, artinya yang dapat lebih mudah memahami pesan dan tujuan yang ingin disampaikan. 
KLHK juga melakukan pendekatan kepada Pemerintah Daerah untuk mendapatkan dukungan uji coba kantong plastik berbayar mengingat bahwa gerai-gerai ritel berada di bawah peraturan Pemda. Dasar pemilihan 23 kota sebagai lokasi pelaksana uji coba adalah karena kota-kota tersebut merupakan kota besar dan pastinya lebih banyak memiliki gerai ritel sehingga menjadi sasaran yang tepat dan pemikiran bahwa masyarakat di kota besar akan lebih dapat menerima kebijakan ini. KLHK juga berkomunikasi dengan LSM, Komunitas pencinta lingkungan seperti Gerakan Anti Plastik, Gerakan Indonesia Diet Kantong Plastik, dan lain-lain sebagai perpanjangan tangan untuk meneruskan pesan mengenai tujuan dilaksanakannya uji coba kantong plastik berbayar ini kepada masyarakat Indonesia. Pesan yang disampaikan oleh KLHK adalah kebijakan kantong plastik berbayar guna mengurangi sampah plastik.

Metode yang dipilih yaitu informatif dan edukatif, sehingga dalam setiap komunikasinya selalu disampaikan fakta dan data mengenai besarnya sampah plastik yang dihasilkan oleh peritel, mengenai bahaya sampah plastik, mengenai kondisi perairan yang tercemar oleh sampah plastik, dan data sejenis. Pesan dan metode ini dimaksudkan untuk dapat menggiring komunikan ke arah perubahan perilaku yang diharapkan yaitu mengurangi penggunaan plastik yang kantong plastik saat berbelanja ke ritel modern.

Mengenai saluran komunikasi yang digunakan dalam penyampaian kebijakan ini diakui oleh Bapak Ujang bahwa KLHK lebih banyak menggunakan media massa (cetak) untuk menyebarkan mengenai uji coba kantong plastik ini. Hal ini terkait dengan anggaran Kementerian dimana untuk sosialisasi, edukasi dan kampanye bukan merupakan hal yang prioritas. Karena itu saluran komunikasi yang lebih banyak digunakan oleh KLHK adalah melalui rapat tatap muka/pertemuan, dialog atau melalui acara bincang-bincang seperti talk show. Namun demikian, bermitra dengan APRINDO, YLKI dan LSM peduli lingkungan membantu penyebaran informasi melalui saluran-saluran lain seperti media sosial dan iklaniklan masyarakat.

Berikut adalah beberapa saluran komunikasi dan media yang digunakan untuk mensosialisasikan mengenai kebijakan kantong plastik berbayar. Sebagai instansi pemerintahan, KLHK banyak menggunakan cara formal untuk berkomunikasi yaitu dengan melakukan pertemuan atau rapat untuk membahas penerapan kebijakan, hingga saat program berjalan dan membahas monitoring dan evaluasi kebijakan. Selain komunikasi langsung antara KLHK dengan APRINDO, komunikasi kepada APRINDO juga dilakukan oleh Pemerintah Kota setempat, maupun oleh Badan Lingkungan Hidup. Sehingga pada praktiknya komunikasi mengenai kebijakan kantong plastik berbayar sebagai langkah antisipasi penggunaan sampah plastik secara aktif terus dilakukan dengan APRINDO.

Kebijakan kantong plastik berbayar ini tentunya harus diketahui oleh masyarakat luas agar dalam pelaksanaannya tidak akan menimbulkan polemik dan tanda tanya. Berita mengenai 
kebijakan ini dikomunikasikan pula melalui bantuan banyak media massa, baik tradisional maupun elektronik. Peranan media kita ketahui masih menjadi strategi komunikasi yang sangat efektif dan masih sangat menjadi favorit karena jangkauan dari media sangat luas, tidak hanya skala lokal, tetapi juga nasional, bahkan juga bisa internasional tergantung dengan kebutuhan.

Dengan banyaknya pemberitaan ini diharapkan masyarakat mengerti maksud dan tujuan diberlakukannya kebijakan kantong plastik berbayar ini dan tujuan akhir untuk mengurangi sampah plastik dapat dicapai. Setelah komunikasi dari KLHK kepada Aprindo, dan Aprindo kepada para anggotanya, maka yang paling penting setelahnya adalah bagaimana para peritel melakukan komunikasi kepada para konsumennya. Karena itu KLHK mengharuskan peritel untuk memasang bentuk komunikasi di masing-masing gerai berupa pengumuman atau keterangan bahwa kantong plastik tidak lagi gratis. Sesuai dengan metode yang dipilih oleh KLHK dalam strategi komunikasinya, maka KLHK membuat bentuk informasi infografis seperti di bawah ini yang memberikan edukasi mengenai sampah dalam pengumumannya sehingga memberikan pengertian kepada konsumen mengapa kini kantong plastik tidak lagi diberikan secara gratis.

\section{Gambar 2. Infografis dari KLHK mengenai Kebijakan Kantong Plastik Berbayar}

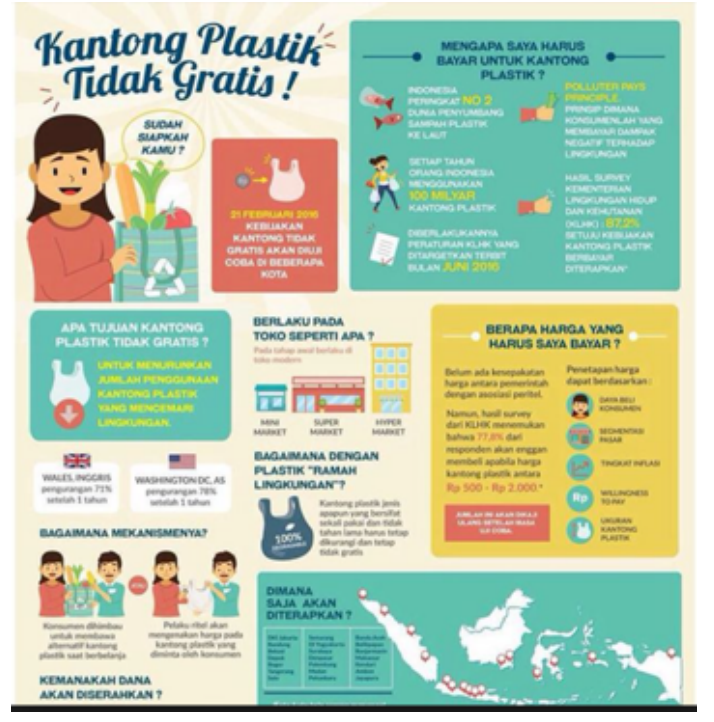

\section{Evaluasi}

KLHK dalam melaksanakan uji coba kantong plastik berbayar adalah dengan melakukan monitoring dan evaluasi. KLHK melakukan monitoring dan evaluasi di 5 kota administratif di Provinsi DKI Jakarta dan 22 kota (27 kota). Bapak Ujang mewakili Lingkungan Hidup dan Kehutanan (KLHK), menyatakan " KLHK berani mengatakan bahwa uji coba kantong plastik berbayar ini sukses atau berhasil karena data kami menyatakan bahwa terjadi pengurangan penggunaan kantong plastik hingga 55\% dan penerimaan masyarakat terhadap uji coba ini 
mencapai $80 \%$. Berarti selama 4 bulan kita melakukan uji coba, kita telah berhasil menghilangkan 55\% sampah plastik yang harus kita tangani. Ini sebuah tingkat keberhasilan yang tinggi, dan berdasarkan data ini cukup sekali bagi kami (KLHK) untuk menyusun draft regulasi lebih lanjut untuk disahkan sebagai peraturan."

\section{SIMPULAN}

Pelaksanaan strategi komunikasi uji coba kebijakan kantong plastik berbayar yang dilakukan oleh Kementerian Lingkungan Hidup dan Kehutanan sebagai berikut: (1) Mengenal khalayak. KLHK memulai strategi komunikasinya dengan mendekati APRINDO sebagai asosiasi dari pengusaha, YLKI sebagai lembaga kemasyarakatan dan BPKN sebagai badan perlindungan untuk konsumen dan Pemerintah Daerah karena menyadari bahwa kebijakan kantong plastik berbayar yang ingin diuji coba memerlukan dukungan dari berbagai pihak agar dapat mencapai proses implementasi. Pengenalan khalayak merupakan tahapan pertama yang harus dijalani dalam strategi komunikasi. Dan pemilihan berbagai pihak ini didasari bahwa ke semuanya dapat membantu keberhasilan tujuan strategi komunikasi yaitu membantu sosialisasi kepada masyarakat Indonesia di 23 kota besar sebagai pelaksana uji coba; (2) Menyusun pesan. Setelah mengenal khalayak, menyusun pesan merupakan strategi selanjutnya. Penyusunan pesan dilakukan melalui banyak pertemuan, rapat, dan forum diskusi. Tujuannya adalah supaya didapat kesepakatan yang sama sehingga tidak ada pihak yang merasa dirugikan pada saat pesan mulai dikomunikasikan dan kebijakan diimplementasikan; (3) Metode yang dipilih oleh KLHK dalam mensosialisasikan uji coba kebijakan kantong plastik berbayar adalah metode informatif dan edukatif. Pesan dikemas dalam bentuk presentasi dengan data dan fakta untuk memberikan gambaran mengapa kebijakan kantong plastik berbayar diperlukan. Ini juga dibuktikan dengan membuat infografis ajakan untuk mengurangi penggunaan kantong plastic; (4) Seleksi dan Penggunaan Media. KLHK juga memanfaatkan media dalam penyebaran informasi uji coba kebijakan kantong plastik berbayar. Ini terbukti dengan banyaknya pemberitaan di media massa baik cetak maupun online mengenai hal ini. Meskipun tidak ada kampanye besar-besaran karena keterbatasan anggaran, namun penggunaan media lain dibantu oleh komunikasi oleh para mitra yaitu APRINDO dan LSM pencinta lingkungan; (5) Evaluasi. Selama uji coba kebijakan kantong plastik berbayar dilakukan telah berhasil mengurangi $55 \%$ penggunaan plastik dan $80 \%$ masyarakat menerima kebijakan ini. 


\section{DAFTAR PUSTAKA}

Arifin, A. (2004). Strategi Komunikasi. Bandung, Indonesia: Armico.

Effendy, Onong Uchjana. (2009). Komunikasi Teori dan Praktek. Bandung : PT Remaja Rosdakarya.

Gogte, M.(2009). Are Plastic Grocery Bags Sacking The Environment? Internasional Journal For Quality Research, Vol. 3 No.4: 362-363

Pandin, M. L. (2009). Potret Bisnis Ritel di Indonesia: Pasar Modern. Economic Review, 215: 112.

Solichin, A. W. (2008). Analisis Kebijakan, Dari Formulasi Ke Implementasi Kebijaksanaan Negara. Jakarta, Indonesia: PT Bumi Aksara. 